\title{
Clark Level V
}

National Cancer Institute

\section{Source}

National Cancer Institute. Clark LevelV. NCI Thesaurus. Code C94816.

A morphologic finding indicating that the cutaneous melanoma has invaded the subcutaneous tissue. 